\title{
DINAMIKA TRANSISI KOMUNITAS WETU TELU DALAM KEYAKINAN PELAKSANAAN SYARI'AT ISLAM
}

\author{
Sri Hariati \\ Fakultas Hukum Universitas Mataram \\ Lombok, NTB, Indonesia \\ Email: Srihukum80@gmail.com
}

\begin{abstract}
Abstrak
Tujuan yang ingin dicapai adalah Untuk mengetahui keberadaan komunitas Wetu Telu dan mengetahui bagaimana dinamika transisi komunitas Wetu Telu dalam pelaksanaan keyakinan syar'at Islam. Di Dusun sangiang Desa kumbang Kecamatan masbagik Lombok timur. Metode yang digunakan dalam penelitian ini adalah penelitian empiris dengan subyek penelitian antara lain, tokoh adat Wetu Telu, tokoh agama Wetu Telu dan masyarakat Wetu Telu serta tokoh agama, tokoh masyarkat wetu lima dan aparatur desa seperti kadus, kepala desa. Komunitas Wetu Telu yang ada di Dusun Sangiang Desa Kumbang Masbagik saat ini masih dalam proses verifikasi ke pelaksanaan syari'at Islam, keberadaan mereka sangat minoritas tapi sebagian mampu bertahan di atas masifnya proses verifikasi oleh para pendakwah. Mereka dalam melaksanakan adat istiadat tidak seperti dulu karna seiring dengan perkembangan zaman dengan majunya pendidikan dan banyaknya sarjanasarjana sehingga mereka melaksanakan ibadah dan tradisi-tradisi tertentu dilaksanakan secara sembunyi-sembunyi.
\end{abstract}

Kata Kunci: syari'at islam;wetu telu

\section{A. PENDAHULUAN}

Kata Sasak selalu dinasabkan pada suku Sasak, sebuah suku, yang menghuni pulau Lombok, sekaligus merupakan penduduk asli pulau ini. Dewasa ini pulau Lombok tren orang Sasak tidak hanya dikonotasikan pada penduduk asli Lombok tetapi migran maupun warga yang lahir di daerah percampuran antara suku Sasak dengan suku yang lainpun disebut sebagai orang Sasak. Sedangkan kata Sasak yang dimaksud dalam tulisan ini terlepas dari sekat-sekat, tensitas, maupun kultur, adalah mereka yang masih berpegang pada ritual dan adat istiadat serta kepercayaan Wetu Telu, tanpa melihat apakah ia penduduk asli (indigienus) maupun pendatang yang notabenenya berdarah campuran (nonindegienus).

Sasak merupakan penduduk asli dan kelompok etnis mayoritas, populasinya lebih dari $90 \%$ penduduk Lombok. Tidak semua penduduk Lombok bisa dikatagorikan sebagai penganut Wetu Telu, sebagian dari mereka sudah tercerahkan dengan adanya purifikasi agama yang dibawa oleh tokoh agama masingmasing. Mereka yang beragama Hindu, beranggapan bahwa mereka merupakan agama yang benar,demikaian pula halnya dengan pengikut agama yang lain, seperti Islam dan Budha, yang beranggapan bahwa agama yang dianutnya adalah agama yang benar menurut keyakinan keagamaannya. ${ }^{1}$

Biasanya kelompok-kelompok penganut Wetu Telu menempati daerah-daerah terpencil dan primitif, sementara kelompok-kelompok lain yang merasa diri sudah tercerahkan kebanyakan menempati tempat yang umum lebih ramai dan lebih mudah di jangkau oleh jalur transportasi. Mereka ini kelompok-

${ }^{1}$ Islam Sasak: Pola keberagaman komunitas Islam Lokal di Lombok.webcache.googleusercontent.com.diakses tanggal 2019-03-21. 
kelompok penganut Wetu Telu yang komunitasnya kecil dan dalam masa transisi keyakinan pelaksanaaan syariat Islam ( waktu lima).

Agama Islam adalah agama yang dianut oleh mayoritas masyarakat Sasak, dengan jumlah penganut mencapai $90 \%$, adapun pengaruh Islam di Lombok dapat dikelompokkan menjadi dua golongan, yaitu:

1. GolonganIslamwaktulima(Islamicortodox seck), yaitu golongan yang mengikuti Islam sesuaidenganajarandanketentuanal-qur'an dan al-hadits.

2. Golongan Wetu Telu, yaitu golongan yang dalam praktik kehidupan sehari-hari masih berpegang teguh pada tradisi nenek moyang serta adat istiadat yang diwariskan secara turun temurun. Pelaksanaan ibadahnya hanya dilakukan oleh kiayi, penghulu dan tokoh-tokoh adat mereka ${ }^{2}$

Sebelum memeluk agama Islam masyarakat Sasak percaya terhadap roh dan kekuatan-kekuatan gaib (animisme dan dinamisme). Mereka percaya bahwa tidak saja dalam benda hidup terdapat suatu benda halus, nyawa, arwah atau semangat tetapi pada tanaman seperti pohon-pohon yang besar yang sudah berusia puluhan bahkan ratusan tahun, benda-benda mati seperti gunung, sungai,lembah, bukit juga terhadap beragam senjata seperti keris, tombak (jongkat: Sasak), ikat pinggang atau sabuk, cincin, akik dan sejenisnya diyakini memiliki kekuatan, roh dan semangat yang selalu mengelilingi manusia baik di rumah maupun di luar rumah. Keyakinan-keyakinan masa lalu ini, hingga saat ini masih dipegang dan dipertahankan oleh penganut Wetu Telu hingga dalam mempersonifikasikan ajaran dan doktrin-doktrin keagamaan berdasarkan tata cara dan penerapannya dengan penganut agama yang lazim dijumpai di berbagai kalangan.

Penganut Wetu Telu, dalam mempersentasikan ajaran-ajaran keagamaan

\footnotetext{
${ }^{2}$ Meneropong strategi kebudayaan melalui kesadaran historis. 2018 "islam wetu telu" jurnal filsafat.ISSN 25286811.
}

sering sekali menonjolkan beberapa pengaruh dan doktrin-doktrin dari berbagai dan beberapa tradisi pendahulunya (budaya lokal, Hindu dan Islam ) yang sebelumnya pernah berkembang di Lombok .

Adanya defereansasi ritual dan tata caracara peribdatan, dengan di dukung oleh adat istiadat yang lebih eksklusif, serta tradisi statis warisan leluhur yang mewarnai polapola keagamaan penganut Wetu Telu Sasak serta belum adanya upaya sistematis pernakpernik tersebut dalam satu konsep.

Perlu juga penulis kemukakan varian Wetu Telu dalam menentukan permulaan bulan Ramadhan (puasa). Terdapat perbedaan pendapat dikalangan varian Islam Wetu Telu yang terbagi dalam tiga kelompok, yaitu:

a. Kelompok pertama, kelompok yang berpegang pada penanggalan yang disebut aboge (reboage), permulaan puasa jatuh dikalangan mereka pada tanggal satu bulan ramadhan.

b. Kelompok kedua, kelompok yang berpegang pada penanggalan kamis pahing, permulaan puasa kalangan ini jatuh pada tanggal dua bulan Ramadhan.

c. Kelempok ketiga, kelompok yang berpegang pada penanggalan jum'at pon, permulaan puasa dikalangan mereka senantiasa jatuh pada tanggal tiga bulan Ramadhan.

Perlu di kemukakan masing-masing kelompok varian Wetu Telu yang berbeda kyai atau penghulunya dalam mengaktualisasikan ajaran Islam tersebut, sebagai berikut:

1. Di Bayan dan Tanjung (Lombok Barat), hanya melaksanakan shalat jum'at dan shalat jenazah, shalat idul fitri, idul adha dan berpuasamulaipadatanggalduaRamadhan.

2. Di wilayah Pujut (Lombok Tengah), dan sekitarnya hanya melaksanakan shalat lima waktu sehari semalam termasuk shalat jum'at shalat idul fitri,idul adha dan shalat jenazah. Mereka memulai puasa pada tanggal satu Ramadhan, dibandingkan dengan wilayah lainnya, kondisi Islam Wetu Telu di desa tersebut masih kuat sampai saat ini. 
3. Di wilayah Rambitan (Lombok Tengah), Sepit(Lombok Timur)dan sekitarnyahanya melaksanakn shalat magrib dan isya selama bulanRamadhan, dan shalatsubuh padapagi hariraya(id),kemudianmelaksanakanshalat jum'at, shalat sunnat tarawih dan shalat jenazah.

4. Di wilayah Pengadangan (Lombok Timur) dan sekitarnya hanya melaksanakan shalat lima waktu sehari semalam selama giliran merebotnya (penjaga masjid) selama tujuh hari setelah itu mereka hanya melaksanakan shalat jum'at, shalat jenazah dan shalat tarawih pada bulan ramadhan.

5. Di wilayah Sembalun(Lombok Timur) dan sekitarnyahanyamelaksanakan shalatashar padaharikamis,shalatzuhurpadaharijum'at dan shalat subuh pada hari raya (id). ${ }^{3}$

Ajaran penganut Wetu Telu mayoritasnya memegang prinsip-prinsip sebagai berikut :

1. Taat kepada tuhan yang Maha Esa

2. Taat kepada pemerintah

3. Taat kepada kedua orang tua, dalam arti yang sangat luas, mereka sangat kuat memegang prinsip-prinsip ini dan tidak berani melanggarnya apalagi menyangkut penaliq yaitu suatu hal yang mereka anggap tabu.

Islam sebagai agama yang dibawa oleh nabi besar Muhammad SAW, sejak lima belas abad yang silam telah berkembang dan tersebar keseluruh penjuru dunia. Agama yang bersifat universal ini sesuai dengan firman Allah SWT dalam al-qur'an surat al-Anbiya :107 yaitu : " Dan tidaklah kami mengutus (Muhammad SAW) melainkan menjadi rahmat semesta alam". Untuk memeluk agama Islam, seseorang seseorang hamba Allah SWT tidak dipaksa akan tetapi atas dasar kesadaran dan hasil pemikirannya yang sehat, tugas para muballig hanya mengajak hamba Allah lainnya untuk tidak menyembah selain Allah. Al-qur'an dengan tegas menyatakan : "tidak ada paksaan untuk

${ }^{3}$ Zuhdi,Muhammad Harfin. 2012. Islam wetu telu di bayan lombok. Akademika: jurnal Pemikiran Islam (dalam bahasa inggris).ISSN 2356-2420. memesuki agama Islam sesungguhnya telah jelas jalan yang benar daripada jalan yang salah karena itu barang siapa yang ingkar thogut (setan), dan beriman kepada tali yang amat kuat yang tidak akan putus. Dan Allah maha mendengar lagi maha mengetahui. ${ }^{4}$

Kelompok-kelompok Wetu Telu masih tersebar di seantero pulau Lombok. Diatas penulis memberikan gambaran lokasi (wilayah) komunitas Wetu Telu yang masih eksis hingga sekarang, Desa Sembalun Lombok Timur, Desa Bayan Lombok Barat, Desa Lembuak Lombok Barat.

Adapun komunitas Wetu Telu yang basis komunitasnya kecil dan eksistensi generasinya mulai redup terdapat dibeberapa daerah, salah satunya di Dusun sangiang Desa kumbang Kecamatan masbagik lombok timur. Ritual-ritual adat dan keberadaan pemangku, kyai dan tokoh adatnya masih eksis sampai sekarang.

Exsitensi penerapan ajaran wektu telu di Dusun sangiang memang diakui mulai berkurang namun beberapa diantara mereka masih berpegang teguh pada perinsip-perinsip ajaran-ajaran Islam Wetu Telu itu tercermin dari perilaku adat-istiadat, pola hidup tradisional yang kental melekat dikeseharian mereka. Pelaksanan ibadah sebagi exsistensi ajaran Islam Wetu Telu masih terlihat. Kelompok Islam Wetu Telu ini berkiblat pada pelaksanan Islam Wetu Telu pada umumnya, dalam komunitas ini yang melaksanakan solat lima waktu sehari semalam serta ajuran solat jumat hanya dilakukan oleh kiyai nya saja.

Aktivitas-aktivitas berikutnya adalah, komunitas ini melaksanakan ritual-ritual khusus, ritual-ritual tersebut dilaksanakan berdasarkan peristiwa-peristiwa yang sifatnya tertentu antara lain, yang berhubungan dengan siklus manusia : kelahiran, perkawinan, kematian atau juga yang berhubungan dengan bercocok tanam : panen raya, menyamikan benih, keluarnya biji padi dan ritual-ritual khusus lainnya seperti lulus dalam suatu

${ }^{4}$ Sulaiman,Achmad 2017. Tradisi Islam Wetu Telu: Dari maleman Qunut Hingga Lebaran Tinggi.Nusantaranews (dalam bahasa inggris). 
pekerjan, sembuh dari penyakit, nazar dan sebaginya. Bentuk-bentuk exsistensi berikutnya adalah kepercayan akan adanya kekuatan-kekuatan supernatural pada bendabenda tertentu antara lain keris, tombak (jungkat), jimat, singe (kayu yang dibentuk menyerupai kuda yang digunakan sebagi alat hiburan untuk pengantin dan anak yang dihitan, biasanya alat ini digunakan untuk mengarak pengantin dan anak yang dihitan).

Indikasi-indikasi bahwa komunitas Islam Wetu Telu tidak semuagenerasinya bergerak pelan kepelaksanan sariat Islam kaffah adalah masih kurang kesadaran mereka untuk membuka diri terhadap dunia luar. Kegiatan-kegiatan dakwah sering mereka dengar namun kurang diterima dengan baik serta kurang ada keinginan untuk mendalami dan memperbaiki kesempurnan sariat Islam. namun Para wali atau orang tua tidak segansegan untuk menyekolahkan anak-anaknya baik keluar kecamatan maupun kabupaten bahkan dan amat kontras dengan dekade sebalumnya.

Selain menempati daerah yang mudah di jangakau oleh fasilitas umum keberadaan mereka juga tidak jauh dari kegiatan-kegiatan dakwah, sehingga memungkinkan adanya dialog yang intens antara generasi Wetu Telu dengan generasi Wetu Lima (Islam kaffah). Penganut Wetu Telu di dusun sangiang desa kumbang kecamatan masbagik Lombok Timur, yang saat ini dalam masa transisi kekeyakinan pelaksanaan syari'at Islam ( $k a f f a h)$ dipengaruhi oleh keberadaan kegiatan dakwah oleh ustaz sadri Qh. Kegigihan beliau dalam berdakwah telah membawa perubahan yang positif bagi komunitas Wetu Telu dalam keyakinan pelaksanaan syar'at Islam di wilayah tersebut. Kegiatan beliau diawali dengan mendirkan masjid di dusun tersebut kemudian melakukan pembinan-pembinan lewat pengajian mingguan yang sampai hari ini masih beliau lakukan, kemudian berikutnya beliau mendirikan lembaga pendidikan sebagi wadah tempat pembinan formal dan non formal.
Pembangunan lembaga dalam dunia pendidikan yang ada di wilayah dusun sangiang, juga tidak dipungkiri sebagai faktor perubahan positif tersebut. Pemerintah dalam hal ini Departemen Agama dan pendidikan setempat, merujuk pada GBHN tahun 1993 menyatakan " pendidikan agama bukan saja wajib diberikan di jalur sekolah, akan tetapi juga pada jalur luar sekolah. Dan juga peran organisasi-organisasi Isalm diyakini berpengaruh terhadap komunitas tersebut seperti NW dan NU.

\section{B. METODE PENELITIAN}

Pendekatan yang digunakan dalam penelitian ini adalah penelitian kualitatif. Penelitian kualitatif merupakan prosedur penelitian yang menghasilkan data deskriptif berupa kata-kata tertulis atau lisan dari orang-orang dan perilaku perilaku yang diamati. Penelitian menggunakan pendekatan kualitatif karena dalam mengungkapkan gejala dan penomena dinamika teransisi komunitas wetu telu kedalam pelaksanan sareat Islam

Hal ini sesuai dengan tujuan penelitian yang menggunakan metode deskriptif, yaitu suatu metode yang menggambarkan keadaan atau peristiwa yang tertuju pada pemecahan masalah dengan cara mengumpulkan data, menyusun, menganalisis dan menarik kesimpulan hasil penelitian.

\section{PEMBAHASAN}

A.Keberadaan komunitas Wetu Telu di dusun sangiang desa kumbang Kecamatan masbagik Lombok Timur.

Wetu Telu dalam Konteks Syari'at Islam

a. Sejarah Masuknya Islam di Pulau Lombok

Ada tiga kesimpulan tentang pengkajian teori-teori masuknya Islam di pulau Lombok:

1. Versi pertama mengatakan bahwa Islam masuk di Lombok sekitar abad ke-15. Versi ini didukung oleh penelitian Tito 
Adonis yang menyatakan bahwa Islam pada mulanya dibawa oleh Syekh Nurur Rasyid dari Jazirah Arabia yang singgah dan menetap di Bayan Lombok Barat. Kemudian Syeikh tersebut menikah denganjandadandikaruniaiseorangputra bernama Zulkarnain yang selanjutnya menjadi cikal bakal raja Selaparang (Islam). Apabila masalah ini dikaitkan dengan masalah keruntuhan kerajaan Majapahit dan berdirinya kerajaan Demak, maka dapat dipahami bahwa peristiwa itu terjadi sekitar abad ke$15 \mathrm{M}$. Pendukung lain dari versi ini adalah temuan baru yang dikemukakan oleh wacana dan kawan-kawan yang menyatakan bahwa masuknya Islam di Lombok adalah antara tahun 1450-1540, dibawaolehseorangmuballighdaripulau Jawa. Nama muballigh tersebut tidak dikemukakan, sehingga menimbulkan pertanyaan, apakah ia Sunan Prapen ataukah muballigh lain.

2. Versi kedua menyatakan bahwa Islam masuk di pulau Lombok sekitar abad ke16. Versi ini didukung oleh Wacana dan kawan-kawan dalam penelitian mereka yang menyatakan bahwa Islam masuk di pulau Sasak sekitar abad ke-16 M dan dibawa oleh Sunan Prapen, keturunan Sunan Giri. Pendukung lain dari versi ini terdiri dari dua macam pendapat. Pendapat pertama adalah pendapat yang menyatakan Islam masuk di pulau LombokberasaldariMakasarlewatpulau SumbawadandibawaolehSunanPrapen. Sedangkan pendapat kedua adalah yang menyatakan bahwa Islam masuk ke Lombok dari pulau Jawa atas instruksi Sunan Pengging dari Jawa Tengah.

Terdapat perbedaan dari informasiinformasi tersebut. Yang pertama penyebutan nama Sunan Prapen sebagai pembawa Islam dari arah timur (Sumbawa), yang oleh Wacana tidak disebutkan demikian. Sedangkan yang kedua adalah pernyataan tentang masuknya Islam melalui Sumbawa, adalah pada abad ke-16 dan bukan abad ke-17 M.

3. Adapun versi ketiga menjelaskan bahwa masuknya Islam di pulau Lombok di mulai sejak abad ke-17 M. Agama ini berasal dari Goa, Sulawesi Selatan dan disebarkan melalui pulau Sumbawa, sebagai mana yang telah dikemukakan oleh Prof. Mahmud Yunus dan diperkuat oleh Mattulada dalam informasinya tentang muballigh yang berada di Goa dan berasal dari Minangkabau. ${ }^{5}$

\section{b. Varian Wetu Telu}

Kapan varian Islam Wetu Telu lahir atau muncul pertama kali dalam masyarakat Sasak, tidak begitu jelas. Akan tetapi diduga kuat, bahwa latar belakang lahirny varian Wetu Telu tersebut akibat proses pengIslaman yang pada mulanya mengikuti tata cara wali atau muballig yang datang dari pulau Jawa setelah runtuhnya kerajaan Majapahit. Islam masuk secara damai dan berhadapan dengan kepercayaan serta adat istiadat yang sudah ada dalam masyarakat lokal. Dengan cara bijak terjadi Islamisasi pada kepercayaan dan adat istiadat tersebut, kepercayaan kepada Allah SWT. Kepercayaan dan adat istiadat yang bertentangan dengan ajaran Islam setahap demi setahap dihilangkan karena ketebatasan waktu dan tenaga para juru dakwah atau muballig saat itu, sebelum sampai pada tujuan akhir yakni mengamalkan Islam secara sempurna ( kaffah ), proses ini terputus di tengah jalan. Akibatnya muncul penerapan ajaran Islam yang tidak murni, campuran ajaran Islam dengan keperccayaan lama mereka.

Dalam kaitannya dengan kemunculan varian Islam Wetu Telu, ada pendapat lain yang mengatakan bahwa variann ini muncul karena adanya program penghinduan yang dilakukan oleh seorang pedande bernama Dangkian Nirarka yang dikirim oleh raja Gelgel dari Bali pada tahun 1930. pedande tersebut dengan cerdiknya meramu ajaran Animisme, Dinamisme, Hindu, Budha dan Islam yang

${ }^{5}$ Solihin, Ahmad. 2012. Memelihara Hubungan Harta dan Keyakinan.Bandung : Sinar Baru Algensindo. 
merupakan kepercayaan lama masyarakat, sehingga merupakan singkreatisme dari agama-agama atau kepercayaan tersebut. Proses Penghinduan ini semakin gencar, terutama raja Gusti Nengah dari kerajaan Karang Asem Bali menaklukkan kerajaan Selaparang sekitar tahun $1740 .^{6}$

Sementara itu, pendapat lain mengatakan bahwa timbulnya varian Islam Wetu Telu sebagai akibat dari usaha belanda dalam mewujudkan pertentangan antara kaum muslimin. Setelah dapat menguasai pulau Lombok pada tahun 1894, pemerintah Hindia Belanda berusaha mencari taktik untuk menguasai orang-orang Sasak penganut Islam Wetu Lima. Untuk itu, diciptakanlah istilah Islam Wetu Telu.

\section{c. Spritualitas Keagamaan Wetu Telu}

Dalam hubungannya dengan praktek ibadah penganut Wetu Telu, terdapat perbedaan yang signifikan dengan praktek ritual kelompok Islam orthodok, termasuk perbedaaan ritual berdasarkan daerah yang berlainan perbedaan-perbedaan yang ada tidak jelas pedoman dan sumbernya kecuali apa yang mereka temui dan dapatkan dari para leluhur mereka. Bacaan shalat umumnya sama dengan yang dipakai oleh kelompok Islam orthodok, hanya mengenai waktu pelaksanaannya yang berbeda pada masingmasing daerah. Umumnya yang mengerjakan shalat hanya para kyai dan santri serta beberapa tokoh adat lainnya. Menurut keyakinan mereka segala dosa dan tanggung jawab, semuanya dibebankan dan ditanggung oleh para kyai dan oleh sebagian orang yang sudah menegerjakan shalat tersebut (hukum shalat bagi mereka adalah fardhu kifayah dan fardhu a'in).

Penganut Wetu Telu, selain kyai dan beberapa pemimpin adat merasa hanya berkewajiban untuk melakukan segala hal yang telah ditentukan dan diperintahkan oleh para kyai mereka. Dan merupakan suatu

${ }^{6}$ Heddy Sri Ahimsa, Putra. 2009. Strukturalisme LéviStrauss, Mitos Dan Karya Sastra. Yogyakarta: Kepel Press larangan berat bagimereka untuk mengerjakan shalat, termasuk mempelajarinya.

Dalam kasus ini, hegemoni politik dan kekuasaan sengaja dikoptasi oleh para kyai dan pemimpin adat, agar mereka tidak kehilangan reputasi mengenai perbedaan waktu shalat pada masing-masing daerah penganut Wetu Telu, dapat digambarkan sebagai berikut;

1. Kelompok Pujut, Rambitan dan Sapit.

Kelompok Pujut, pada mulanya mengerjakan shalat lima waktu sehari semalam, dan menunaikan hampir semua anjuran shalat sunnat serta shalat jum'at. Namun setelah penganut Wetu Telu Pujut terpecah manjadi dua kelompok (Wetu Telu hitam dan Wetu Telu putih), kelompok Wetu Telu hitam, meninggalkan cara ini dan bergabungdengankelompokpenganut Wetu Telu Bayan, adapun Kelompok Rambitan dan Sapit,merekahanyamengerjakan shalat padaharijum'at.Selainmerekamengerjakan shalat jum'at, mereka juga mengerjakan shalat magrib dan isya. Sementara pada hari lainnya mereka tidak shalat kecuali pada waktuharirayaIdulFitri.selainmengerjakan shalat hari raya, pada hari ini juga mereka mengerjakan sahalat ashar, yang tidak dikerjakan pada hari-hari lainnya:

2. Kelompok Bayan dan Lembuak

Mengenai kelompok Lembuak hampir sama dengan kelompok Bayan, di mana mereka tidak mengenal shalat lima waktu para kyai hanya shalat dalam empat perkara:

a. Shalat Jum'at

b. Shalat Jenazah

c. Shalat hari raya Idhul Fitri

d. Dan beberapa shalat sunnat lain yang dikerjakan pada bulan-bulan tertentu seperti tarawih (kendati tidak sama jumlah rakaat dan tata- caranya dengan penganut Islam kebanyakan).

3. Kelompok Sembalun 
Para kyai kelompok Sembalun hanya mengerjakan shalat dalam tiga waktu;

a. Shalat subuh dan shalat Idul Fitri setiap tanggal 1 Syawal

b. Shalat zuhur pada hari jum'at

c. Shalat ashar pada hari kamis.

Kelompok ini tidak mengerjakan shalat magrib dan isya', tetapi mereka mengerjakan shalat sunnat tarawih pada bulan Ramadhan dan shalat jenazah.

Pengnut Islam Wetu Telu mengklaim dirinya sebagai penganut agama Islam, bahkan dapat dikatagorikan sebagi kelompok yang sangat penatik dalam beragama, namun disisi lain masih memegang dan menganggap tradisi dan juga adat istiadat yang diwarisi oleh leluhur sebagai bagian integral yang tak terpisahkan dari pengamalan keagaman mereka. Padahal jika dirunut sistem nilai yang mereka yakini memiliki banyak pertentangan dengan normatifitas Islam. Jadi, teologi Islam Wetu Telu yang masih mempertahankan tradisi atau adat istiadat, juga secara apresiatif merespon beberapa stimulan dan unsur-unsur baru dari agama Islam (Islam Waktu Lima). ${ }^{7}$

Kedua, Islam Wetu Telu bukan merupakan sebuah agama, dan tidak pula sebagai salah satu paksi dalam Islam. Tetapi lebih tepat jika dikatakan bahwa Wetu Telu adalah sebuah institusi keagaman yang berkembang dilingkungan masyarakat Sasak Lombok sebagai sebuah singkretisasi keagamaan yang mengakomodir transisi kepercayaan lokal, nilai-nilai Islam dan unsur-unsur Hindu, yang terbentuk karna dilatarbelakangi oleh bebrapa faktor antara lain : (1) Sinkretisme keagamaan (2) Terputusnya Islamisasi (Stagnasi Dakwah) serta belum adanya program perifikasi dari para mubalig muslim (3) Hegemoni politik Dan Kekuasan (4) Eksklusifisme Adat Dan Aristokerat, Lombok. ${ }^{8}$

Mayoritas masyarakat Sasak adalah penganut varian waktu lima. Istilah "Islam

${ }^{7}$ Budiawanti erni.2010. islam sasak, yogyakarta, PT LKIS, yayasan Adikarya IKAPI dan Ford foundation.

${ }^{8}$ Budiman, Arif. 2009. Teori Pembangunan Dunia Ketiga. Jakarta : PT. Gramedia Pustaka Utama waktu lima" muncul sebagai pembanding dari lahirnya istilah "Islam Wetu Telu". varian Islam waktu lima adalah varian Islam yang menjalankan ajaran agama sesuai Al-qur'an dan Hadis Nabi terutama dalam masalah Akidah, Syari'ah Mu'amalah dan Akhlak. Mereka melaksanakan rukun Islam dengan sempurna, seperti kewajiban shalat yang lima waktu sehari semalam, yakni Shalat Subuh, Zuhur, Ashar, Magrib dan Isya, tanpa mewakilkan kepada siapapun. Demikian pula halnya puasa, zakat dan haji.

Menjelaskan secara rinci kemajuan yang telah dicapai dari aktualisasi ajaran Islam waktu lima di Lombok, sangatlah sulit khususnya sebelum abad ke-dua puluh masehi. Hal ini disebabkan karena tidak ada atau kurangnya data. Memang, dalam bentuk lontar atau babad disinggung tentang Islam, tetapi sebatas cerita tentang peristiwa yang terjadi pada suatu kerajaan, bukan menyangkut hal-hal yang berkaitan dengan Islam berikut aktualisasinya ajarannya secara spesifik. $^{9}$

Penganut Islam waktu lima mayoritas merupakan anggota masyarakat yang tergabung dalam beberapa organisasi sosial, keagamaan. Organisasi sosial keagamaan yang terkenal dalam kalangan Islam waktu lima adalah Nahdtaul Wathan (NW) dan Nahdatul Ulama (NU). Kedua organisasi ini adalah pengikut Mazhab Syafi'i (Syafi'iyah) serta merupakan kelompok Ahlussunnah Waljama'ah. ${ }^{10}$

Fathurrahman Zakaria memperkirakan bahwa Mazhab Syafi'i mulai masuk di Lombok sekitar pertengahan abad kesembilan belas Masehi. Akan tetapi menurut bebrapa bahwa pada pertengahan abad ke sembilan belas masehi.

Buat mazhab ini telah berkembang pesat. Karena didukung oleh para Tuan Guru yang telah kembali dari tanah suci setelah mereka

\footnotetext{
${ }^{9}$ Muads Abdullah. 2013. Sistem Pendidikan Ikhwanul Muslimin. Jakarta: Bina Mitra Press.

${ }^{10}$ Agus Bustanudin. 2012. Agama Dalam Kehudupan Manusia. Jakarta: PT. Raja Grafindo Persada.
} 
belajar ilmu-ilmu agama disana. Sehingga masuknya mazhab ini pertama kali ke pulau Lombok sebelum abad ke-19 M.

Pulau Lombok merupakan tempat tinggal suku Sasak. Mayoritas masyarakat di sana menganut agama Islam. Namun, ada sebagian orang Islam Sasak yang memiliki praktik keagamaan Islam tersendiri yang disebut Wetu Telu. Banyak orang mengartikan istilah wetu telu atau waktu tiga merujuk pada praktik yang dilakukan komunitas di sana untuk meringkas shalat yang lima waktu menjadi tiga waktu. Namun, istilah wetu telu sendiri merujuk pada filosofi yang bermakna bahwa terdapat tiga hal penting yang mewarnai setiap kehidupan di alam semesta. Misalnya, ada tiga jalan kemunculan makhluk hidup, yaitu melahirkan (manganak), bertelur (menteluk), dan berbiji (mentiuk). Filosofi ini berarti bahwa manusia harus menjaga keseimbangan dan hubungan yang harmonis dengan alam. Alam sangat penting artinya bagi komunitas ini. Sebab itu, ada berbagai macam aturan adat yang melarang tindakan merusak alam. Kelestarian alam sangat dijaga oleh komunitas adat ini. Lalu ada tiga siklus keberadaan manusia, yaitu alam rahim atau kandungan, alam dunia, dan alam akhirat. Komunitas Wetu Telu percaya bahwa hidup pada dasarnya memiliki siklus dan tingkatan yang dimulai dari kelahiran, beranak pinak, hingga kematian. Mereka meyakini bahwa saat memasuki status atau tingkatan yang lebih tinggi, haruslah dilaksanakan ritual tertentu yang dapat menghindarkan mereka dari gangguan-gangguan hidup.

Pandangan umum mengatakan adanya Islam Wetu Telu sebagai akibat dari para penyebar Islam terdahulu yang ingin mengenalkan keislaman secara bertahap. Namun, mereka meninggalkan Lombok sebelum mereka mengajarkan Islam dengan lengkap. Akibatnya terjadi sinkretisme antara agama Islam dengan Hindu dan Buddha. Pemahaman tersebut berkembang luas sehingga Wetu Telu mendapat stigma negatif. Digambarkan bahwa mereka hanya shalat tiga waktu, bukan lima waktu seperti yang seharusnya. Namun tudingan itu tidak berdasar. Orang Wetu Telu tetap melaksanakan Rukun Islam dan Rukun Iman. Yang menjadi sumber pandangan negatif adalah karena di samping melaksanakan tradisi Islam, mereka juga menjalankan adat istiadat asli masyarakat Sasak. Jadi, istilah "Wetu Telu" bukan merujuk pada nama agama atau kepercayaan tersendiri. Istilah ini merujuk pada filosofi masyarakat di sana yang percaya bahwa hidup mencakup tiga hal penting, seperti masa lalu-sekarang-masa depan atau kelahiran-kehidupan di duniakematian. Dengan demikian, istilah tiga waktu tidak merujuk pada berapa kali mereka shalat dalam satuhari seperti yang banyak dimengerti oleh kebanyakan orang.

Islam Wetu Telu mempertahankan salah satu ciri utama dari kepercayaan lokal yang tersebar di seluruh Nusantara, yaitu menonjolnya peran leluhur dalam kehidupan manusia. Dalam pandangan Wetu Telu, kematian tidak berarti pemisahan. Arwaharwah para leluhur yang telah berpindah ke alam lain tetap memiliki hubungan dengan anak-cucunya. Mereka berperan sebagai pelindung dan pengayom, menjaga keturunannya dari marabahaya yang tidak diinginkan.

Untuk itu, mereka sangat menghormati leluhur. Salah satunya dengan menjaga warisan leluhur, seperti rumah, tanah, maupun benda pusaka lain, juga dengan berbagai upacara adat. Sampai saat ini, kaum Muslim Wetu Telu masih mendokumentasikan garis silsilah keluarga pada lembaran daun lontar dengan huruf Jawa Kuno yang hanya boleh dibaca oleh tokoh adat pada saat-saat tertentu. ${ }^{11}$

Sejarahnya wetu telu di dusun sangiang pada tahun 1950 an yang lalu keberadaannya masih 99\% pengikutnya dan sampai sekarang jumlah pengikutnya sudah berkurang, namun sebagian dari penganut wetu telu yang ada di sangiang saat ini masih bertahan turun temurun, islam wetu telu yang ada

\footnotetext{
${ }^{11}$ Abidin zainal.2011.filsafat manusia, bandung, PT Remaja Rosdyakarya.
} 
di sangiang sama dengan islam wetu telu yang ada di tempat lain. Mereka masih mengutamakan adat istiadat daripada hokum syariat dalam berkegiatan, mereka masih menganut kepercayaan yang sama persis dengan kepercayaan nenek moyang mereka terdahulu yaitu animism dan dinamisme dan bisa di lihat dari proses-proses acara adat mereka. Dulu ketika wetu telu masih besar di dusun sangiang ini terdapat beberapa orang saja yang tidak ikut kepercayaan islam wetu telu tersebut dan jumlahnya sekitar 4 orang yang ada di sangiang dan mereka adalah pendatang yaitu papuk tahir,papuk mahdi,papuk lisah,papuk puyah. Terdapat contoh adat istiadat yang mereka laksanakan misalnya Kalau ada orang tua mereka meninggal dunia maka diantara anak-anaknya mengadakan musyawarah, tujuannya adalah untuk menentukan prosesi adat mulai dari mengkafani sampai proses 40 hari. Dan disini biasanya selalu ada perdebatan diantara anak keturunan si mayat. Kalau ada diantara anak keturunan si mayat ada yang pindah keyakinan ke islam wetu lima, maka disinilah terjadi perdebatan tersebut yaitu proses bagaimana yang seharusnya diterapkan kepada si mayit mulai dimandikan sampai proses selesai, dan biasanya siapa yang paling kuat ketika beradu diantara anak-anaknya yang menganut waktu lima dan waktu telu maka yang menang tersebut berhak mengurus si mayit sampai proses selesai. Dan juga kalau ada yang minum minuman keras diantara mereka, maka mereka tidak menganggap diri mereka berdosa. Dan kiyai di sini, dulu meminta persetujuan raden sueno serta anakanaknya untuk menasihati tokoh islam waktu lima agar tidak merekrut pengikut wetu telu untuk pindah ke keyakinan islam waktu lima, dan semua perintah raden sueno itu diikuti oleh tokoh islam wetu lima pada waktu itu, dan raden sueno berbicara ke tokoh waktu lima dan dia mengatakan "jangan ganggu anak buahku (masyarakat wetu telu) biarkan mereka apa adanya dan apapun mereka maka dan bagaimanapun mau mereka perbuat asal mereka tidak mengganggu kalian semua (islam wetu lima). Kata-kata raden sueno itu yang dipegang oleh kiyai dan mempertahankan anak buahnya dan tetap mentaati aturan yang dibuat oleh raden sueno tersebut dan dipertahankan oleh kiyai.

Dan salah satu contoh perbedaan wetu telu dan waktu lima di sini ketika proses pemakaman jenazah dimana kiyainya menerapkan apa yang dia terima dari nenek moyangnya seperti ketika proses membaca talkin, dibaca di awal dan di akhir saja dan cara penguburannya tetep sama dan dilaksanakan pada malam hari dan tidak diumumkan di masjid dan cukup lewat hp dan kadang juga dilaksanakan pada siang hari jam 12 ketika keadaan sedang sepi dan ketika tengah malam/dini hari sekitar jam 3 dini hari para keluarga berbondong-bondong ke kuburan untuk menjenguk jenazah dan membawakan makanan dan minuman/dulang yang berisi air kelapa dan makanan. Biasanya kalau ada kiyainya yang meninggal dunia, pasti akan digantikan oleh anaknya secara otomatis. Mereka mendahulukan adat istiadat daripada hokum islam itu sendiri. ketika mengadakan acara penobatan kiyai baru disahkan oleh kiyai sepuh. Pengangkatan kiyai dinobatkan oleh kiyai sepuh di rayakan dulu dengan begawe besar atau pesta sampai potong sapi dan kambing kemudian dimandikan dan basuh muka dibersihkan kemudian dinobatkan sebagai kiyai baru dan tidak boleh berprilaku dalam kesehariannya seperti orang biasa. ${ }^{12}$

Pekerjaan yang berat dalam melaksanakan adat istiadat mereka terlihat ketika adanya perkawinan. Dalam perkawinan ini acaranya banyak atau prosesnya banyak yaitu a). acara taubat dulu, kalau belum taubat mereka tidak boleh bertemu dan saling melayani antara calon mempelai. Mediasi taubat mereka adalah kiyainya. b). tidak boleh kerja yang berat sebelum dilaksanakan pernikahan. menikahnya sambil pesta jadi didahulukan adat istiadat dulu baru hokum agamanya,

${ }^{12}$ Biosard, Macel A. 2014. Humanisme Dalam Islam. JAKARTA : Bulan Bintang. 
kalau waktu lima yang didahulukan hokum syariat dulu baru adat. ${ }^{13}$

Mereka dalam melaksanakan adat istiadat tidak seperti dulu karna seiring dengan perkembangan zaman dengan majunya pendidikan dan banyaknya sarjana-sarjana sehingga mereka melaksanakan ibadah dan tradisi-tradisi tertentu dilaksanakan secara sembunyi-sembunyi.

Dalam prosesi pernikahan misalnya pihak laki dari wetu telu dan pihak perempuan dari waktu lima. Maka keluarga pihak perempuan turun tangan untuk menikahkan secara hokum islam dan pihak wetu telu harus mentaati awiq-awiq atau peraturan yang diberikan pihak perempuan tersebut dan berjanji akan mengikuti kepercayaan mempelai wanita baru pihak wanita memberikan wali dan mau menikahkan anaknya. Secara hokum prosesi pernikahan ini sangat berbeda dengan syariah islam dari segi ucapan dan lafaz nikah. Mereka memakai bahasa sasak yang mirip bahasa bali dan tidak dimengerti oleh masyarakat waktu lima. Dan mereka tetap mendokrin anak keturunan mereka agar tetap menganut wetu telu. Dan anak-anak mereka sudah mulai sering ke masjid untuk mengaji dan sholat. Tapi tetap saja bagi orang tua mereka tidak menerapkannya hanya sebagai pengetahuan mereka saja agar bisa seimbang dengan masyarakat waktu lima.

A. Bagaimana dinamika transisi komunitas Wetu Telu dalam pelaksanaan keyakinan syari'at Islam di Dusun sangiang, Desa kumbang, Kecamatan masbagik Lombok Timur?

Penganut Wetu Telu biasanya menempati tempat-tempat terpencil dipedesaan, lerenglereng gunung, disekitar rimbunan hutan yang lebat atau ditepian aliran sungai. Hal ini selaras dengan kepercayaan mereka yang bercorak animis, dinamis, antropomarpis dan pantis. Kehidupan mereka sehari-hari mereka peroleh dengan bertani, berkebun dan sedikit diantara mereka yang menjadi peternak dan pengrajin.

${ }^{13}$ Sztompka Piotr, 2013, Sosiologi Perubahan Sosial, Jakarta, prenada
Umumnya, penganut Wetu Telu tergolong masyarakat yang masih murni dan belum terpolarisasi dengan ide-ide globalisasi maupun modern budaya mereka masih asli, belum terjamah kontemporer, termasuk masyarakat yang masih suci batin dan perbuatannya, yang akan selalu berbuat baik menurut adat istiadat nenek moyang dan leluhur mereka tidak suka mencuri, berbohong dan berbagai macam perbuatan yang merugikan orang lain. Mereka ratarata lurus dan jujur, patuh kepada orang tua dan pemimpin mereka, menghargai orang lain serta menghormati orang yang lebih tua. Berusaha menjaga persahabatan dan memiliki kebutuhan yang sangat minim, serta punya rasa tanggung jawab terhadap keluarga, kerabat dan tetangganya. ${ }^{14}$

Islam datang ke Indonesia, termasuk yang datang ke tengah-tengah masyarakat Sasak Lombok, dari arah manapun, tidaklah masuk dalam ruang yang hampa melainkan mengalami proses perbauran dengan sosiokultural masyarakat setempat. Kebudayan yang berkembang sebelum Islam tersebut kemudian berdialog dengan ajaran baru yang dibawa oleh Islam yang berbeda. Dari sini terlihat jelas kemudian apa yang disebut dengan universalisme Islam. Kondisi suatu wilayah memang sangat menentukan corak dan warna keberagaman masayarakat. Sehingga dijumpai suatu wilayah ada yang sadar dengan berpengang pada ajaran-ajaran Islam, normatif, namun ditempat yang lain akan dijumpai masyarakat yang kemungkinan tata dan sangat ketat berpegang pada nilainilai lainya, seperti adat dan keyakinankeyakinan sebelum datangnya Islam atau dapat kita temukan percampuran antara semua bentuk pengaruh dan budaya yang telah mempengaruhi budaya dan keyakinan mereka. ${ }^{15}$

Seperti yang telah diuraikan sebelumnya bahwa komunitas Wetu Telu adalah komunitas

\footnotetext{
${ }^{14}$ Prof. Dr. Tafsir Ahmad, 2013, filsafat ilmu, bandung, PT Remaja Rosdakarya

${ }^{15}$ Dukheim, Emile. 2012. Sejarah Agama. The Elementary forms of the religious Life. Jogjakarta: IRCiSoD.
} 
varian Islam atau penganut ajaran Islam yang pada saat itu proses dakwah dalam rangka Islammisasinya terputus, sehingga pelaksanan sariat Islam belum sempurna dilaksanakan seperti penganut Islam pada umunya.

Kelompok Islam Wetu Telu yang basis sosial kulturalnya lebih terbuka dan lebih awal terjangkau oleh pasilitas-pasilitas umum, pada umumnya lebih mudah terpolarisasi oleh proses Islammisasi kedalampelakasanan sariat Islam yang sempurna (kaffah). kelompok ini mulai membuka diri untuk belajar menerima dan melaksanakan Islam secara sempurna. Di tengah pergeseran-pergesaran yang terjadi memang sulit, berjalan pasif dan kadang menimbulkan komplik itu dipahami karna komunitas ini tidak bisa dipaksakan untuk secepatnya memeluk agama Islam secara sempurna.

Komunitas Wetu Telu yang mau menerima ide-ide moderen dan berfikir terbuka adalah mereka yang saat ini sedang dalam masa teransisi. Perubahan sosial kultural dan etika pelaksanan sariat agama Islam yang kontras dengan sebelumya memberikan jawaban bahwa pada komunitas ini mengalami peralihan dekade, perpindahan zaman dan keyakinan. Membuka lapangan kerja baru, bersosialisasi dan berkomunikasi dengan masyarakat pada umumnya, mengabaikan perihal yang irasional dan bergerak menata hidup lebih rasional. ${ }^{16}$

Munculnya komplik terkadang juga tidak terhindari dalam hal ini Islam Wetu Telu dan penganut Islam wktu lima. Generasi yang berdampingan seringkali memicu terjadinya komplik sosial tetapi tetap dalam batas kewajaran paling tidak dalam bentuk keresahan dan itu hanya dari segelintir saja yang sulit menerima ajaran baru, karena seuadah merasa dirnya terdesak dan terkikis.

Pada awalnya, mereka memang tidak memberi jalan dan berusaha bertahan, terhadap kedatangan para muballigh misalnya kedatangan TGH yang membawa

${ }^{16}$ Zaelani Kamarudin. 2017. Satu Agama Banyak Tuhan (Melacak Sejarah Teologi Wetu Telu). Gomong Mataram: Pantheon Media Pressindo. ajaran tarekat, namun karena kegigihan para mubaligh tersebut yang berusah memasuki wilayah mereka serta berbagi metode dan sarana pendidikan formal disamping non formal memaksa mereka untuk menerima dan meyakini pelaksanan sareat Islam yang sempurna. Ketergesakaan mereka sifatnya tidak dipaksa namun dengan memberikan dakwah-dakwah yang bersifat halus dan damai. hal ini bisa dibuktikan dengan semakin terkikisnya jumlah mereka yang bertahan pada keyakinan semula dan semakin banyaknya jumlah mereka yang dengan positif menyempurnakan keiIslaman mereka dengan menyempurnakan ajaran Islam yang sebenarnya sesuai dengan yang dilakaukan oleh kelompok Islam wetu lima. Terutama dari kalangan generasi muda yang lebih cepat berfikir terbuka dan lebih rasional.

Kalaupun sementara ini, di Desa dan wilayah tertentu implementasi program Islamisasi dan akulturasi nilai-nilai Islam kedalam kebudayaan masyarakat sangat lamban dan pasif bahkan di daerah tertentu tidak ada sama sekali, hal ini disebabkan belum terwujudnya program yang intensif dalam rangka mewujudkan proses Islamisasi dan akulturasi nilai-nilai Islam, disebabkan pula karena adanya kesulitan-kesulitan dalam menerapkan program yang direncanakan di wilayah tertentu sebagaimana yang terjadi dikalangan sebagaian kelompok Wetu Telu di Bayan.

Sebelum menutup pembahasan ini, ada beberapa faktor penting yang selama ini dipandang telah berfungsi sebagai pendukung suksesnya progaram Islamisasi dan akulturasi nilai-nilai Islam kedalam masyarakat yang masih menganut faham Islam Wetu Telu. Faktor-faktor tersebut antara lain: peranan pendidikan dan keluarga, fungsi masjid dan mushalla, lembaga-lembaga organisasi keIslaman, peranan pemerintah pengaruh mistisme (Tasawuf dan Tareqat), pengaruh media, pengaruh seni dan budaya. ${ }^{17}$

\footnotetext{
${ }^{17}$ Solihin, Ahmad. 2012. Memelihara Hubungan Harta dan Keyakinan.Bandung : Sinar Baru Algensindo.
} 
Dulu orang yang tidak menganut wetu telu Cuma ada 4 orang yang ada di sangiang dan mereka adalah pendatang yaitu papuk tahir,papuk mahdi,papuk lisah,papuk puyah. Ketika mereka melaksanakan sholat mereka mengajak masyarakat wetu telu untuk sholat di musholla kecil di situ mereka yang menganut wetu telu diajarkan sholat teraweh,sholat lima waktu dan ngaji. Mereka berbondong-bondong masuk ke waktu lima karna mereka merasa berat atas adat yang dilaksanakan tersebut. Dan siapapun boleh pindah kepercayaan ke waktu lima dan diserahkan ke tokoh agama.

Dalam beribadah islam wetu telu dusun sangiang percaya adanya tuhan ibu, tuhan bapak dan tuhan anak (Nenek inak nenek amak tuhan anak) makanya dijuluki wetu telu. Acara adat yang paling berat adalah Kalau ada kematian di kalangan masyarakat wetu telu tersebut, dimana prosesnya mulai dimandikan sampai seratus hari kematiannya harus dipersiapkan dulang dan semua harta bendanya habis diberikan ke kiyai mereka. Misalnya ada 10 orang kiyai maka keluarga yang meninggal tersebut harus mempersiapkan 10 dulang,10 kain,10 baju dsb pokoknya selengkapnya. Kalau ada yang meninggal dunia di dusun sangiang ini,maka pasti mereka menggadai dan menjual sawah ladang mereka untuk biaya acara prosesi kematian tersebut. Setiap 9 hari,40 hari-100 hari mereka harus membawa dulang dll ke rumah kiyai-kiyai tersebut. Sama dengan mengeluarkan fitrah,mereka harus berikan zakat fitrah tersebut ke kiyai mereka dan tidak boleh ke orang lain. Kalau puasa mereka puasa di awal 3 hari dan di akhir puasa 3 hari. Keberadaan mereka masih banyak dan sembunyi-sembunyi karna mereka merasa malu karna sering mendengar azan di masjid dan melihat tetangga mereka yang pergi sholat ke masjid dan lama kelamaan mereka malu sendiri dan sembunyi-sembunyi dalam melaksanakan adat istiadat yang mereka anut sampai sekarang. Mereka menyekolahkan anak mereka dan menyuruh anak mereka tujuannya adalah untuk pergi mengaji untuk menguatkan keyakinan mereka (wetu telu) supaya bisa mengimbangi waktu lima, kalau waktu lima bisa baca talkin dan mengaji, mereka juga bisa seperti itu, agar pengikutnya tidak banyak yang pindah kepercayaan ke waktu lima, jadi ini tujuan mereka agar bisa mengimbangi. Kalau anak mereka disekolahkan sampai tingkat yang lebih tinggi misalnya sekolah ma'had atau ma'hadah pasti anak mereka tidak bisa dipengaruhi/doktrin oleh orang tua dan kiyai mereka tapi kalau masih di tingkat aliyah atau sma maka anaknya bisa dipengaruhi/ doktrin. Mereka menyekolahkan anaknya tujuannya hanya sebatas mengetahui tapi tidak menerapkannya karna semata-mata untuk mengimbangi pengetahuan mereka. Makanya masyarakat wetu telu itu jarang ada yang bisa kaya karna setiap ada acara adat seperti perkawinan,kematian selalu mengeluarkan harta benda mereka, sampai para kiya berpesan ke orang waktu lima agar tidak mengganggu keberadaan wetu telu tersebut karna para kiyai tersebut merasa terancam pendapatannya.

\section{KESIMPULAN}

Islam Wetu Telu mempertahankan salah satu ciri utama dari kepercayaan lokal yang tersebar di seluruh Nusantara, yaitu menonjolnya peran leluhur dalam kehidupan manusia. Dalam pandangan Wetu Telu, kematian tidak berarti pemisahan. Arwah-arwah para leluhur yang telah berpindah ke alam lain tetap memiliki hubungan dengan anak-cucunya. Mereka berperan sebagai pelindung dan pengayom, menjaga keturunannya dari marabahaya yang tidak diinginkan. Untuk itu, mereka sangat menghormati leluhur. Salah satunya dengan menjaga warisan leluhur, seperti rumah, tanah, maupun benda pusaka lain, juga dengan berbagai upacara adat. Sampai saat ini, kaum Muslim Wetu Telu masih mendokumentasikan garis silsilah keluarga pada lembaran daun lontar dengan huruf Jawa Kuno yang hanya boleh dibaca oleh 
tokoh adat pada saat-saat tertentu. Dalam beribadah islam wetu telu dusun sangiang percaya adanya tuhan ibu, tuhan bapak dan tuhan anak (Nenek inak nenek amak tuhan anak) makanya dijuluki wetu telu. Acara adat yang paling berat adalah Kalau ada kematian di kalangan masyarakat wetu telu tersebut, dimana prosesnya mulai dimandikan sampai seratus hari kematiannya harus dipersiapkan dulang dan semua harta bendanya habis diberikan ke kiyai mereka.

\section{DAFTAR PUSTAKA}

Abidin zainal, 2011, filsafat manusia, bandung, PT Remaja Rosdyakarya.

Agus Bustanudin. 2012 Agama Dalam Kehudupan Manusia. Jakarta: PT. Raja Grafindo Persada.

Arikunto, Suharsimi. 2010. Prosedur Penelitian. Jakarta: Rineka Cifta.

Biosard, Macel A. 2014. Humanisme Dalam Islam. JAKARTA : Bulan Bintang.

Budiman, Arif. 2009. Teori Pembangunan Dunia Ketiga. Jakarta: PT. Gramedia Pustaka Utama.

Dukheim, Emile. 2012. Sejarah Agama. The Elementary forms of the religious Life. Jogjakarta: IRCiSoD.

Dr. Budiawanti erni, 2010, islam sasak, yogyakarta, PT LKIS, yayasan Adikarya IKAPI dan Ford foundation.

Heddy Sri Ahimsa, Putra. 2009. Strukturalisme Lévi-Strauss, Mitos Dan Karya Sastra.

Yogyakarta: Kepel Press

Islam Sasak: Pola keberagaman komunitas Islam Lokal di Lombok.webcache. googleusercontent.com.diakses tanggal 2019-03-21.

Meneropong strategi kebudayaan melalui kesadaran historis "islam wetu telu" jurnal filsafat.ISSN 2528-6811.2018
Muads Abdullah. 2013. Sistem Pendidikan Ikhwanul Muslimin. Jakarta: Bina Mitra Press.

Scharrf R. Betty. 2014. Sosiologi Agama. Jakarta: Kencana.

Zaelani Kamarudin. 2017.SatuAgama Banyak Tuhan (Melacak Sejarah Teologi Wetu Telu). Gomong Mataram: Pantheon Media Pressindo.

Widyanta, AB. 2012. Sosiologi Kebudayaan George Simmel. Yogyakarta : Cindelaras Pustaka Rakyat Cerdas.

Solihin, Ahmad. 2012. Memelihara Hubungan Harta dan Keyakinan. Bandung : Sinar Baru Algensindo.

Sugiono. 2012. Metode Penelitian Kuantitatif Kulitatif dan $R \& D$. CV: Alfabeta.

Prof. Dr. Tafsir Ahmad, 2013, filsafat ilmu, bandung, PT Remaja Rosdakarya.

Sztompka Piotr, 2013, Sosiologi Perubahan Sosial, Jakarta, prenada.

Zuhdi,Muhammad Harfin. 2012. Islam wetu telu di bayan lombok. Akademika: jurnal Pemikiran Islam (dalam bahasa inggris).ISSN 2356-2420.

Sulaiman,Achmad 2017. Tradisi Islam Wetu Telu: Dari maleman Qunut Hingga Lebaran Tinggi.Nusantaranews (dalam bahasa inggris). 